\title{
PROVIDING A MECHANISM FOR IMPLEMENTING THE STRATEGY FOR IMPROVING THE COMPETITIVENESS OF UKRAINE'S MARITIME TRANSPORT INFRASTRUCTURE
}

\author{
Vladyslav Stepanenko ${ }^{1}$
}

\begin{abstract}
The purpose of the article is to develop a mechanism for implementing a strategy for increasing the competitiveness of the Ukrainian maritime transport infrastructure. Methodology. The mechanism for implementing the strategy for increasing the competitiveness of Ukraine's maritime transport infrastructure should have a systemic and comprehensive nature, all its elements should be interconnected and aimed at achieving a common goal that can guarantee the implementation of the strategic goals and priorities of the proposed concept. Results. The article is devoted to the formation of a mechanism for the implementation of the strategy of increasing the competitiveness of the Ukrainian maritime transport infrastructure, taking into account the European integration orientation. The proposed mechanism consists of key planes and their elements: methodological: (political, administrative, legal, organizational, economic, social methods; principles of consistency and complexity, flexibility, strategic importance, synergy, congruence, integration, innovation, adaptability, consistency, hierarchy; functions: goal setting - planning - organization - motivation - control - coordination); organizational and resource (institutional, organizational, financial, technological, information, socio-economic support); operating room, including a sequence of five stages (I - III stages. Development and adoption of the MTI development program of Ukraine and measures to implement the strategy at all levels of government (mega, macro, meso, micro. IV stage. Implementation of developed measures. V stage. Evaluation of the implementation of the strategy to increase the competitiveness of MTI of Ukraine). Practical implications. The directions of increasing the competitiveness of the Ukrainian maritime transport infrastructure are determined, namely: financial, personnel, regulatory, organizational, information technology and environmental. An algorithm for the implementation of the strategy to increase the competitiveness of the Ukrainian maritime transport infrastructure is presented. Value/originality. It is noted that the proposed mechanism for implementing the strategy for increasing the competitiveness of Ukraine's maritime transport infrastructure in the context of European integration will ensure the constant, efficient, competitive, stable development of Ukraine's maritime transport infrastructure.
\end{abstract}

Key words: maritime transport infrastructure, strategy, European integration, competitiveness.

JEL Classification: F15, L62, L90, N70, Q53

\section{Introduction}

Current state and development trends of the Ukrainian maritime transport infrastructure (reduction of volumes and cargo handling, reducing the attractive image of Ukraine as a reliable counterparty in international transport relations, decrease in competitive positions and profitability of seaports due to depreciation of fixed assets (more than $70 \%$ ), inconsistency of their technical level) testifies to the systemic shortcomings of the internal maritime transport infrastructure management as part of the

\footnotetext{
Corresponding author:

${ }^{1}$ Donetsk National University of Economics and Trade

named after Mykhailo Tuhan-Baranovskyi, Ukraine.

E-mail: st.vlad.1995@gmail.com

ORCID: https://orcid.org/0000-0001-8370-6137

ResearcherID: AAF-4190-2021
}

transport infrastructure of the state. These trends require urgent solutions for effective management and the formation of a mechanism for implementing the strategy to increase the competitiveness of the maritime transport infrastructure, taking into account the European experience of reforms in this industry.

\section{The formation of a mechanism for implementing the strategy}

The mechanism for implementing the strategy for increasing the competitiveness of Ukraine's maritime 
transport infrastructure (MTI) in the context of European integration is consistent, complex and cyclical and is a system of interrelated elements. The proposed mechanism is adaptive and can change its structure by introducing new elements, the appearance of which is the result of a number of adjusted strategic objectives, measures, management methods or resource and operational support.

Comprehensive filling of the mechanism for implementing the strategy for increasing the competitiveness of the MTI with functional elements and resource support will contribute to the effective management of the competitiveness of the maritime transport infrastructure and operational support for the implementation of the strategy.

The implementation of the strategy for increasing the competitiveness of Ukraine's MTI provides for the creation of a mechanism (Figure 1) able to ensure the adoption of effective management decisions, using a set of principles, tools, functions and methods affecting the process of managing the competitiveness of MTI, taking into account the influence of the determinants of managing the competitiveness of MTI in the context of European integration.

Determination of strategic priorities and objectives of the strategy for increasing the competitiveness of the Ukrainian maritime transport infrastructure and on the basis of the tools for implementing the strategy, we will determine the directions of increasing the competitiveness of the Ukrainian MTI, namely: financial, personnel, regulatory, organizational, information technology and environmental direction.

\section{Financial support}

1. State financing or financing at the expense of own funds of the State Enterprise "Ukrainian Sea Ports Authority" (USPA).

2. Financing from extrabudgetary funds, including investor funds.

3. Financing by raising debt capital or issuing shares.

4. Financing through the creation of a joint venture between the port authorities and port stevedore(s), shipowners, cargo owners and others.

\section{Staffing}

The main trend in modern education and training in the field of maritime transport infrastructure should be a shift from supply-side learning to demand-driven learning. The focus should be on individual workers, their productivity and skill level. Also it is necessary to maintain high standards of personnel training and professional competence of crews to ensure the safety of navigation and environmental transportation. Therefore, an adequate basis should be provided for the training and retraining of crews in the form of activities aimed at:

1. Enhancing the image of shipping and a career in the maritime industry.

2. Developing professional highly specialized standards for workers in the field of MTI in accordance with modern requirements.

3. Promoting cooperation between educational organizations and other subjects of maritime transport infrastructure.

4. Creating special departments of professional training on the basis of seaports and reinforcement of training with real practice.

5. Implementing a work quality control system and periodic re-certification of employees.

6. Ensuring presence of clearly formulated general educational principles.

7. Ensuring strict compliance with international and European requirements in accordance with the International Convention on Standards of Training, Certification and Watchkeeping for Seafarers ("International Convention on Standards of Training, Certification and Watchkeeping for Seafarers", 1978).

8. Facilitating the work of the International Maritime Organization (IMO) and the International Labor Organization (ILO) with the Ukrainian government regarding the fair treatment of seafarers.

9. Promoting cooperation between European maritime education institutions and Ukrainian higher education institutions to support the competence of seafarers at the level of prerequisites for the modern development of maritime transport, creating a network of centers of excellence in maritime training.

\section{Regulatory and legal support}

In addition to the main legislative decisions, the development and implementation of which will be necessary for the implementation of strategic directions for the development of MTI, we propose legislative measures that deserve special attention:

1. Bringing the Customs Code of Ukraine ("The Customs Code of Ukraine”, 2012), other regulations and the legal framework of the State Border Guard Service of Ukraine in line with the Convention on Facilitation of International Maritime Traffic1965 ("Convention on Facilitation of International Maritime Traffic", 1965).

2. Continuation of the forward movement in terms of the requirements for ensuring the safety of navigation and the categorization of marine transport infrastructure and vehicles by the competent authorities in the field of ensuring maritime transport security.

3. Improvement and harmonization of legislation to European standards in the field of safety in maritime transport.

4. Harmonization of national legislation in the field of natural monopolies (Law of Ukraine "On Natural 


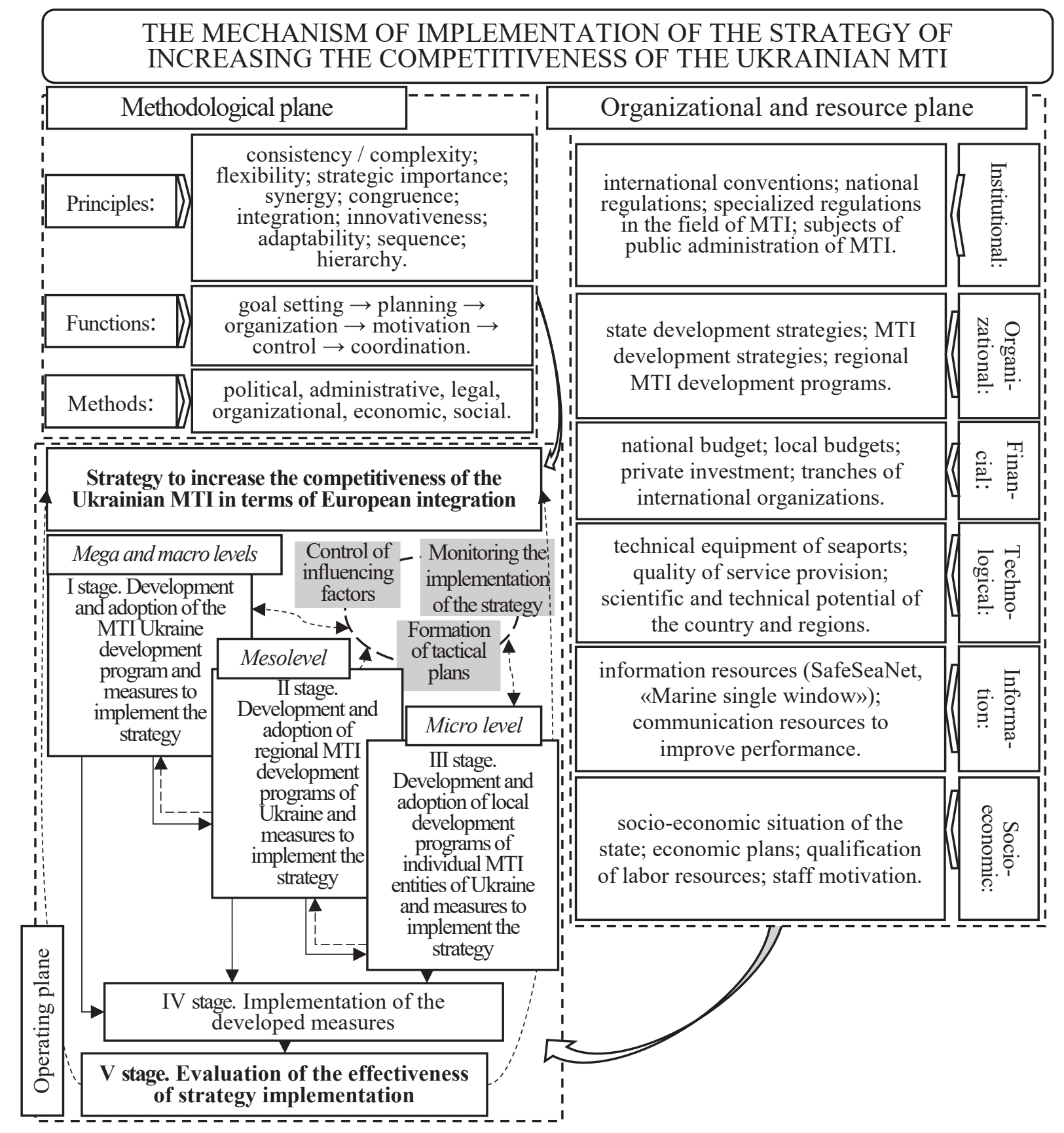

Figure. 1. The mechanism for implementing the strategy to increase the competitiveness of Ukraine's maritime transport infrastructure in the context of European integration

Monopolies" (Law of Ukraine "On Natural Monopolies", 2000)) with the European and international practices for the withdrawal of a part of services in sea terminals, ports, and does not directly affect the speed of commodity and information flows, from under state regulation.

5. Legislative strengthening of ensuring the efficiency and effectiveness of public-private partnership mechanisms in the field of investments in MTI.

6. Improvement and bringing national legislation to the standards of international practice in terms of the distribution of responsibility between the state and entrepreneurship in the field of ensuring safety at the operated objects of maritime transport infrastructure and vehicles.

7. Legislative consolidation of compliance with higher environmental standards, legislative and tax incentives for the introduction of energy efficient and environmental technologies in port activities.

8. Development and adoption at the regional level of the Technical Regulations (set of rules, national 
standards) for the design, construction and operation of hydraulic structures.

9. Amendments to the regulatory legal acts "The Land Code of Ukraine" ("The Land Code of Ukraine", 2001), "The Water Code of Ukraine" ("The Water Code of Ukraine", 1995) and the Law of Ukraine "On Sea Ports of Ukraine" (The Law of Ukraine "On Sea Ports of Ukraine”, 2012) regarding the lands of the water fund occupied by water and water areas of ports in order to simplify the registration procedures property rights of investors to port infrastructure facilities created on the territory of the seaport; facilitation and unification of procedures for the creation of artificial land plots on water bodies in order to enable and simplify the construction of marine infrastructure facilities on the lands of the water fund and the prospective development of infrastructure.

10. Development and approval of the Law of Ukraine "On Clusters". The adoption of this law should outline the following provisions in the legal sphere: definition of the concept of "cluster"; types (territorial, functional, etc.); goals of interaction of cluster members; cluster structures; basic principles of the organization, functioning and termination of the cluster; governing bodies; interaction with state and local government bodies; ownership of property and products or services created by the cluster; rights and obligations of cluster members; state support for the formation of clusters.

11. Adoption of the Law of Ukraine "On Multimodal Transportation", which regulates the "legal and organizational foundations of multimodal transportation in Ukraine and is aimed at creating conditions for their development and improvement, encouraging the use of more environmentally friendly modes of transport in order to protect the environment, prevent climate change and excessive consumption energy" (Draft the Law of Ukraine "On Multimodal Transportation", 2020). This law will promote the development of logistics technology "dry ports".

Note that in the process of implementing the strategy, it is necessary to ensure the clarification and revision of the list of necessary legislative measures, which will reflect the current and already made changes in the legislative framework.

\section{Organizational support}

The mechanism for implementing the strategy provides for the use of a set of organizational measures consists in performing the following management functions: organizing actions (events) that are consistent with the directions of increasing the competitiveness of MTI, laid down in the strategy; motivation of the subjects of MTI; organization and implementation of planned activities; subsequent control of target indicators and production resources for the implementation of strategy activities; coordination (if necessary) of measures of the strategy and their further planning, both on the basis of the adjustment carried out, and on the basis of taking into account modern trends.

Implementation of the mechanism implies coordination of the strategy with the process of making, executing and monitoring decisions in the executive authorities of Ukraine, as a result, the following will be achieved: proper implementation of the strategy; ensuring coordination with the main adopted state, departmental and regional strategies for the development of Ukraine's MTI; adaptation of the strategy to changes in the global and domestic macroeconomic conditions, as well as the prompt adoption of the necessary decisions on the provision of resources for the implementation of activities. We offer the following algorithm for the implementation of the strategy to improve the management of the competitiveness of the Ukraine's MTI (Figure 2):

1. USPA in the role of an authorized representative of the Ministry of Infrastructure of Ukraine in the field of port management determines strategic directions for increasing the competitiveness of the maritime transport infrastructure, which must be consistent with the directions of the national transport strategy developed by the Ministry of Infrastructure of Ukraine.

2. Strategic directions for the development of MTI have been developed and submitted for approval to the Ministry of Infrastructure of Ukraine. After official approval by the Ministry of Infrastructure, the directions should be implemented by the Administrations of development centers (clusters) of MTI within the framework of the agreed resource provision.

3. The administrations of the centers for the development of MTI are responsible for the implementation of the mechanism for increasing the competitiveness of MTI, which must be consistent with the directions of state policy in the field of maritime transport.

4. Within the framework of the general management system, the USPA must annually approve the annual and long-term work plans of the seaports, which include goals, objectives, targets, specific activities and projects that will be implemented, including at their own expense.

\section{Information and technological support}

The formation of conditions for increasing the competitiveness of Ukraine's MTI on an innovative basis requires the activation of state policy to strengthen the innovation and technological component of state development programs, stimulate maritime transport companies to innovate, and introduce state support for innovative and research projects in the MTI. So, to improve information technology support, the following tasks should be implemented. 


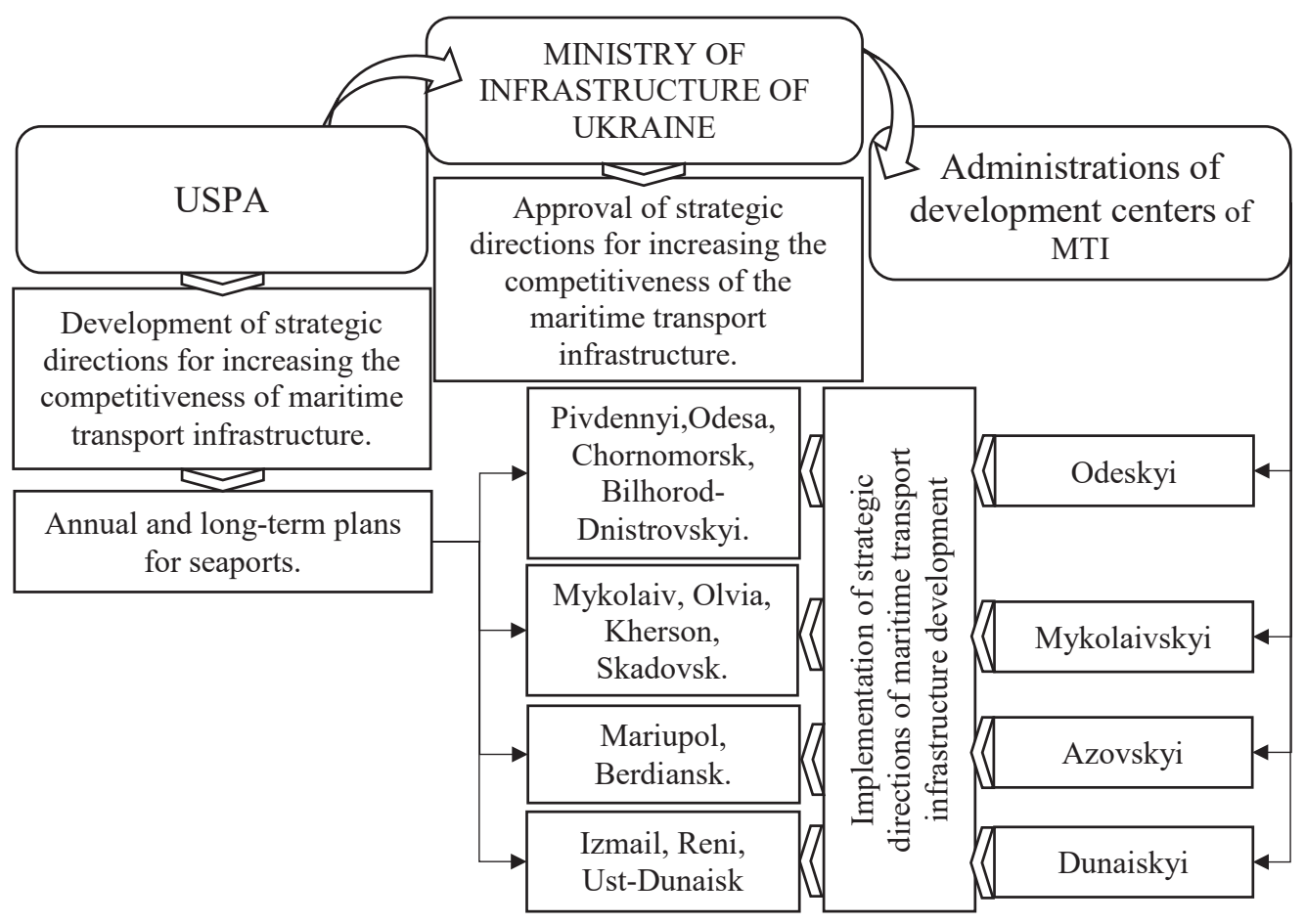

Figure 2. Algorithm for implementing the strategy to increase the competitiveness of Ukraine's maritime transport infrastructure

1. Formation of a system of intermodal and multimodal transportation through the implementation of the "dry port" logistics technology.

We propose the creation of a "dry port" near the city of Rozdilna in Odesa region at the intersection of road and rail International Transport Corridor №9 (Helsinki - Vyborg - Saint Petersburg - Pskov Moscow - Kaliningrad - Kyiv - Lyubashivka/ Rozdilna - Chișinău - Bucharest - Dimitrovgrad Alexandroupolis;), as well as the TRACECA transport corridor ("Europe - Caucasus - Asia") and the "Viking" combined transport train, which passes through the territory of the three states and connects a chain of maritime container and piggyback lines of the Baltic region with a similar system of the Black, Mediterranean and Caspian Seas (freight train running on the route Chornomorsk (Ukraine) - Minsk (Belarus) - Klaipeda (Lithuania)) (VIKING, 2003).

The movement of cargo from the seaport to the "dry port" can be controlled by implementing electronic cargo tracking systems (GSM-GPS navigation system (NAVSTAR)), television image recognition system, intelligent radio frequency labeling system) (Strelnykova, Artemova, 2013).

2. Implementation of joint procedures with the EU to ensure the safety of maritime transport, monitoring of vessel movements, assistance at sea, sea communications, response to ship pollution and the creation of a national segment of the SafeSeaNet information exchange system for maritime traffic and emergencies.
3. Creation of a national system for the exchange of information ("Marine Single Window") on the movement of ships and the functioning of business entities in the MTI, in particular, through international technical and financial assistance.

Implementation of information technology logistics systems into the Ukrainian's MTI, designed to integrate all participants of port transport and cargo processes into a single information space with the ability to provide and access information that is used in technological processes of cargo transportation. The task of the development of information technology logistics is the integration of the Ukrainian MTI into the unified transport and logistics network of the European Union, increasing the competitiveness of the maritime transport infrastructure, forwarding and logistics activities.

\section{Environmental support}

Now the maritime administrations of European countries and the European maritime industry are making considerable efforts to improve the ecological state of shipping. The EU regulatory framework aims to cooperate with member states in the prevention of accidents and accidents, air emissions, ballast water treatment and ship recycling. Thus, the activities of the European Commission are focused on achieving a long-term plan of "zero waste with zero emissions" in the field of maritime transport. Due to the fact that Ukraine is striving for European integration, the 
following tasks for environmental protection have been identified:

1. To provide sustainable development in achieving an integrated and coordinated approach to reducing greenhouse gas emissions from shipping, combining market, technical and operational measures.

2. To organize cooperation with the IMO to reduce or limit greenhouse gas emissions.

3. To achieve "good" ecological status of sea waters under EU sovereignty or jurisdiction.

4. To improve the legislation of Ukraine on port reception facilities for waste, discarded ships and cargo residues, improving the mechanisms for coordinating these operations.

5. To encourage the use of alternative energy sources in seaports through tax exemptions and the development of incentive regulations (e.g., sea wave energy).

6. To increase the effectiveness of Ukraine's participation in the IMO and strengthen international cooperation with the EU's trade and maritime partners, ensuring the safety of navigation.

7. To promote the development of the European Marine Environmental Safety Management System (EMS-MT), which aims to improve the environmental performance of maritime transport continuously by improving port registration and fees and other payments to promote environmentally sound maritime transport.

8. To promote the EU strategies to improve ship dismantling, the adoption of the IMO convention "Hong Kong International Convention for the Safe and Environmentally Sound Recycling of Ships 2009" and continuous progress towards its further implementation.

9. Monitor the amendments adopted by the IMO in 2005 to Annex VI of MARPOL ("The Hong Kong International Convention for the Safe and Environmentally Sound Recycling of Ships”, 2009) to reduce emissions of sulfur and nitrogen oxides from the exhaust gases of ships and the prohibition of deliberate emissions of ozone-depleting substances, as well as mandatory technical and operational measures adopted in 2011 to improve energy efficiency aimed at reducing greenhouse gas emissions from ships.

The strategic priorities, tasks and tools for the implementation of the strategy for increasing the competitiveness of Ukraine's MTI have been determined, which guarantee the achievement of the main goal of the strategy - ensuring a high level of competitiveness of Ukraine's MTI in the context of European integration.

\section{Conclusions}

Thus, the proposed mechanism for the implementation of the strategy for increasing the competitiveness of Ukraine's maritime transport infrastructure in the context of European integration will ensure constant, efficient, competitive, stable development of Ukraine's maritime transport infrastructure. The improved mechanism for implementing the strategy for increasing the competitiveness of the Ukraine's maritime transport infrastructure consists of key planes and their elements: 1) methodological: (political, administrative, legal, organizational, economic, social methods; principles: consistency and complexity, flexibility, strategic importance, synergy, congruence, integration, innovation, adaptability, consistency, hierarchy; functions: goal setting, planning, organization, motivation, control, coordination); 2) organizational and resource (institutional, organizational, financial, technological, information, socio-economic support); 3) operating room, including a sequence of stages (Stage I. Development and adoption of a development program for MTI of Ukraine and measures to implement the strategy; Stage II. Development and adoption of regional development programs for MTI of Ukraine and measures to implement the strategy; Stage III. Development and adoption of local development programs for individual subjects of objects MIT Ukraine and measures to implement the strategy; Stage IV. Implementation of the developed measures; Stage V. Assessment of the implementation of the strategy to increase the competitiveness of Ukraine's MTI). This mechanism will ensure a permanent, efficient, competitive, stable development of the Ukrainian maritime transport. The implementation of a specific strategy is possible through the formation and implementation of strategic directions for increasing the competitiveness of the Ukrainian maritime transport infrastructure, which is aimed at consistent integration into the European and world maritime transport market.

\section{References:}

The official site of IMO (1978). "International Convention on Standards of Training, Certification and Watchkeeping for Seafarers”. Available at: https://zakon.rada.gov.ua/laws/show/995_053 (accessed 03 March 2020).

The Verkhovna Rada of Ukraine (2012). “The Customs Code of Ukraine”. Available at: https://zakon.rada.gov.ua/ laws/show/4495-17\#Text (accessed 19 October 2020).

The official site of IMO (1965). “Convention on Facilitation of International Maritime Traffic". Available at: https://zakon.rada.gov.ua/laws/show/995_064 (accessed 03 March 2020).

The Verkhovna Rada of Ukraine (2000). The Law of Ukraine “On Natural Monopolies”. Available at: https://zakon.rada.gov.ua/laws/show/1682-14\#Text (accessed 20 October 2020). 
The Verkhovna Rada of Ukraine (1994). The Law of Ukraine “On Transport”. Available at: https://zakon.rada.gov.ua/ laws/show/232/94-вp (accessed 22 October 2020).

The Verkhovna Rada of Ukraine (2001). "The Land Code of Ukraine”. Available at: https://zakon.rada.gov.ua/ laws/show/2768-14\#Text (accessed 10 October 2020).

The Verkhovna Rada of Ukraine (1995). “The Water Code of Ukraine”. Available at: https://zakon.rada.gov.ua/ laws/show/213/95-вp (accessed 22 October 2020).

The Verkhovna Rada of Ukraine (2012). The Law of Ukraine "On Sea Ports of Ukraine". Available at: https://zakon.rada.gov.ua/laws/show/4709-17\#Text (accessed 22 October 2020).

The official site of the Ministry of Infrastructure of Ukraine (2020). Draft the Law of Ukraine "On Multimodal Transportation". Available at: https://mtu.gov.ua/ (accessed 10 October 2020).

The official site of VIKING Train (2003). "About the Project". Available at: http://www.vikingtrain.com/ (accessed 10 October 2020).

Strelnykova, I. O., \& Artemova, Yu. O. (2013), Suputnykovi systemy navihatsii i monitorynhu transportu. Avtomobil i elektronika [Satellite transport navigation and monitoring systems]. Vehicle and Electronics. Innovative Technologies, no. 4, pp. 56-52. (in Ukrainian)

The official site of IMO (2009). "The Hong Kong International Convention for the Safe and Environmentally Sound Recycling of Ships". Available at: https://www.imo.org/en/About/Conventions/Pages/The-HongKong-International-Convention-for-the-Safe-and-Environmentally-Sound-Recycling-of-Ships.aspx (accessed 21 October 2020). 